\title{
Działalność krakowskich oficyn wydawniczych na rzecz szkoły i edukacji w dwudziestoleciu międzywojennym
}

Działalność wydawnicza w dwudziestoleciu międzywojennym była skoncentrowana przede wszystkim w Warszawie, gdzie funkcjonowała blisko połowa wszystkich profesjonalnych oficyn edytorskich (291), kolejne miejsca zajmowały: Lwów (78 firm), Poznań (47) i Kraków (46). Mniejszymi ośrodkami były: Wilno (16 oficyn), Łódź (14) i Katowice (11). W pozostałych 49 miejscowościach działało 87 firm 1 .

Odzwierciedleniem tej sytuacji było terytorialne rozmieszczenie wydawców podręczników szkolnych w II RP. Największa ich liczba, co można prześledzić na podstawie spisów podręczników dozwolonych do użytku w szkołach powszechnych w latach 1920/21-1929/30, skoncentrowana była w stolicy kraju, kolejne miejsca zajmowały: Lwów, Kraków, Poznań, Łódź oraz mniejsze ośrodki (zob. tab. 1).

Kraków w tym zestawieniu, z liczbą wydawców wahającą się w poszczególnych latach od 7 do 12, znajdował się na trzecim miejscu. Wśród edytorów były zarówno firmy profesjonalne (Księgarnia Geograficzna „Orbis”, Księgarnia Towarzystwa Szkoły Ludowej, Księgarnia Fabiana Himmelblaua czy Księgarnia Daniela Edwarda Friedleina), jak i wydawcy indywidualni, którzy wydawali podręczniki własnym nakładem.

* Dr, Uniwersytet Pedagogiczny im. Komisji Edukacji Narodowej w Krakowie, Wydział Filologiczny, Instytut Informacji Naukowej i Bibliotekoznawstwa, Katedra Badań Książki i Prasy, 30-084 Kraków, ul. Podchorążych 2.

${ }^{1}$ N. Kraśko, Instytucje wydawnicze w II Rzeczypospolitej, Warszawa 2001, s. 35. Nieco inne wyliczenia poczynił M. Pieczonka w publikacji: Firmy wydawnicze w Polsce w latach 1918-1939 (próba rejestracji ilościowej), „Rocznik Naukowo-Dydaktyczny WSP w Krakowie”, Prace Bibliotekoznawcze V, z. 135, Kraków 1990, s. 41-56. Według niego na pierwszym miejscu pod względem liczby wydawców nadal była stolica, drugie miejsce zajmowały ex aequo Lwów i Kraków, a kolejne: Poznań, Łódź i Wilno. 
Tabela 1. Rozmieszczenie terytorialne wydawców podręczników szkolnych w latach 1921-1930*

\begin{tabular}{|l|c|}
\hline \multicolumn{1}{|c|}{ Miasto } & Liczba wydawców \\
\hline Warszawa & $25-35$ \\
\hline Lwów & $12-17$ \\
\hline Kraków & $7-12$ \\
\hline Poznań & $3-8$ \\
\hline Łódź & $2-5$ \\
\hline Tarnów & $2-3$ \\
\hline Katowice & $1-4$ \\
\hline Cieszyn & $1-3$ \\
\hline Wilno & $1-2$ \\
\hline Mikołów & $1-2$ \\
\hline Włocławek & $1-2$ \\
\hline Płock & $1-2$ \\
\hline Przemyśl & $1-2$ \\
\hline Kołomyja & 1 \\
\hline Złoczów & 1 \\
\hline Gdańsk & 1 \\
\hline
\end{tabular}

* Obliczenia własne na podst. wykazów Ministerstwa Wyznań Religijnych i Oświecenia Publicznego: Spis podręczników szkolnych dla szkół powszechnych siedmioklasowych na rok szkolny 1920/21, Warszawa 1920; Spis podręczników szkolnych dozwolonych do użytku w szkołach powszechnych na rok szkolny 1921/22, Warszawa 1921; Spis podręczników szkolnych dozwolonych do użytku na rok szkolny 1922/23 Rozporządzeniem Ministra Wyzn. Relig. i Oświec. Publicznego L. 929/K z dnia 10 czerwca 1922 roku, wydanie drugie niezmienione, Warszawa 1922; Spis podręczników szkolnych dozwolonych do użytku w szkołach powszechnych na rok szkolny 1923/24 Rozporządzeniem Ministra Wyznań Religijnych i Oświecenia Publicznego, Warszawa 1923; Spis podręczników szkolnych dozwolonych do użytku w szkołach powszechnych na rok szkolny 1924/25, Warszawa 1924; Spis podręczników szkolnych dozwolonych do użytku w szkołach powszechnych na rok szkolny 1925/26, Warszawa 1925; Spis podręczników szkolnych dozwolonych do użytku w szkołach powszechnych na rok szk. 1926/27, Warszawa 1926; Spis podręczników szkolnych dozwolonych do użytku w szkołach powszechnych na rok szk. 1927/28, Warszawa 1927; Spis podręczników szkolnych dozwolonych do użytku w szkołach powszechnych na rok szk. 1928/29, Warszawa 1928; Spis podręczników szkolnych i środków naukowych dozwolonych do użytku w szkołach powszechnych na rok szk. 1929/30, Warszawa 1929.

Procentowy udział podręczników szkolnych wydawanych w Krakowie w całym dorobku krajowych oficyn wydawniczych w tym zakresie nie był wysoki. W latach 1920-1930 odsetek ten wahał się od 3,17\% w roku szkolnym 1920/21 do maksymalnie 5,19\% w roku szkolnym 1924/25; średnio wynosił 4,22\%. W liczbach bezwzględnych spisy odnotowywały od 6 (1920/21) do 20 tytułów (1929/30) „krakowskich” podręczników i książek metodycznych dla nauczycieli, przy ogólnej ich liczbie $189-482^{2}$.

2 Obliczenia własne, źródło: zob. przypis pod tabelą. 
Na czoło krakowskich wydawców podręczników wysuwa się bez wątpienia Księgarnia Geograficzna „Orbis”, której założycielem był Ludomir Sawicki, geograf, profesor Uniwersytetu Jagiellońskiego. Sporo pisał i wydawał drukiem. Aby uniezależnić się od wydawców, założył w 1922 roku pod nazwiskiem swojej żony Marii Księgarnię Geograficzną "Orbis” (Dębniki, ul. Barska 41). W 1924 roku obok księgarni uruchomił drukarnię (Tłocznię Geograficzną). Firma prowadziła skład główny wydawnictw kartograficznych Polskiego Towarzystwa Krajoznawczego, Iwowskiego „Atlasu” oraz zakładu G. Freytag i Berdt w Wiedniu. Sawicki sprowadzał z zagranicy wszelkie publikacje z dziedziny geografii. Nakładem księgarni ukazywały się serie: „Prace Instytutu Geograficznego UJ” (od 1923), „Biblioteczka Geograficzna Orbis” (od 1924) oraz „Krakowskie Odczyty Geograficzne” (od 1924). Ponadto "Orbis” wydawał czasopisma: „Wiadomości Geograficzne” redagowane przez Sawickiego (od 1923), „Orli Lot” (od 1924) i „Wierchy” (1926-1931). W ofercie księgarni znajdowały się pomoce naukowe do nauczania geografii, w tym barwne mapy odbijane w Wiedniu. Po śmierci Sawickiego firmę prowadzili spadkobiercy aż do wybuchu II wojny światowej ${ }^{3}$.

Mimo że firma była formalnie zarejestrowana na żonę Sawickiego, tajemnicą poliszynela było jego sprawstwo całego przedsięwzięcia. Powodowało to np. zadrażnienia z prof. Eugeniuszem Romerem, założycielem konkurencyjnego wydawnictwa „Atlas” we Lwowie (1921) 4 .

Ludomir Sawicki opracował w latach 1920-1921 i wydał własnym nakładem szereg podręczników i pomocy do nauki geografii w szkole powszechnej. Książki te znalazły się w publikowanych corocznie przez Ministerstwo Wyznań Religijnych i Oświecenia Publicznego spisach podręczników dozwolonych do użytku w szkołach powszechnych. Podręczniki autorstwa L. Sawickiego były w latach 1920-1930 wielokrotnie wznawiane, niektóre osiągnęły ponad 20 wydań. Zaliczają się do nich następujące pozycje: Elementarz geograficzny. Pogadanki dla I i II stopnia siedmioklasowej szkoły powszechnej (osiem wydań w latach 1920-1930), Geografia dla III stopnia siedmioklasowej szkoły powszechnej (20 wydań w latach 1921-1931), Geografia dla IV stopnia siedmioklasowej szkoły powszechnej (22 wydania w latach 1920-1932), Geografia dla V stopnia siedmioklasowej szkoły powszechnej (14 wydań w latach 1920-1931), Geografia dla VI stopnia siedmioklasowej szkoły powszechnej (8 wydań w latach 1921-1929), Atlas konturowy. Zeszyt I, II i III. Zeszyt I: Polska (17 mapek); zeszyt II: Europa w wydaniu mniejszym (6 mapek) i większym (18 mapek); zeszyt III: Świat (10 mapek) $)^{5}$ Metodyka

${ }^{3}$ S. Wojciechowski, Sawicki Ludomir, [w:] Słownik pracowników książki polskiej, red. I. Treichel, Warszawa-Łódź 1972, s. 789; M. Klimaszewski, Sawicki (Ślepowron Sawicki) Ludomir Juliusz, [w:] Polski Słownik Biograficzny, t. 35, Wrocław 1994, s. 329-332; W. Chełmicki, Ludomir Ślepowron Sawicki (1884-1928): geograf, geomorfolog, hydrograf, antropogeograf, [w:] Złota księga Wydziału Biologii i Nauk o Ziemi. Cz. 1: Biografie uczonych, red. A. Zemanek, Kraków 2000, s. 359-365; Ludomir Sawicki: w osiemdziesiątą rocznicę urodzin (1884-1964), red. M. Dobrowolska, R. Mochnacki, Warszawa 1968.

${ }^{4}$ M. Klimaszewski, Sawicki (Ślepowron Sawicki) Ludomir..., s. 330.

${ }^{5}$ Zeszyt pierwszy kosztował 1,70 zł, drugi 0,70 zł (mniejszy) lub 1,80 zł (większy), trzeci - 1 zł. Można było także nabywać oddzielne mapki po $10 \mathrm{gr}$. 
geografii dla I-III oddziału siedmioklasowej szkoły powszechnej, Kraków 1921, nakład autora (współautor Piotr Hrabyk), Metodyka geografii dla stopnia I szkoły powszechnej, Kraków 1929 (współautor Rudolf Hajnos).

Ponadto Sawicki wydał podręcznik do geografii dla szkół niemieckich w Polsce (Geographie für deutsche Schulen in Polen. I u. II Teil, Kraków 1925).

Rzecz jasna, oprócz niezwykle aktywnej na rynku podręczników i pomocy szkolnych Księgarni Geograficznej „Orbis” działali w Krakowie również inni wydawcy.

Dość licznie reprezentowane działali podręczniki do nauczania religii mojżeszowej. Krakowską proweniencję miały książki autorstwa dra Dawida Rosenmana (kierownika gimnazjum w Białymstoku w roku szk. 1922/23) oraz Salomona Spitzera ${ }^{6}$, nauczyciela gimnazjów i kierownika szkoły wydziałowej na krakowskim Kazimierzu. Zwłaszcza ten ostatni był autorem wielu podręczników do nauki religii żydowskiej w szkołach publicznych stopnia podstawowego, ukazujących się już od lat 80. XIX wieku. Biblia dla młodzieży szkół średnich i wydziałowych, Zeszyty I i II, Dawida Rosenmana wydana została nakładem izraelickiej gminy wyznaniowej w Krakowie w 1921 roku. Z kolei trzy podręczniki Salomona Spitzera: Historia biblijna oraz zasady wiary i moralności. Część I, II i III (wyd. 1 - 1907-1911, wyd. 2 - 1916, wyd. 3 - 1919); Zdrój życia. Zasady wiary i moralności na podstawie Pisma Świętego (wyd. 1 - 1910, wyd. 2 - 1918, wyd. 3 - 1928-1929) oraz Dzieje biblijne, tj. Pięcioksiąg Mojżesza z nauką wiary i moralności dla młodzieży szkół powszechnych, Część I i II (wyd. 5, Kraków 1929), ukazywały się nakładem autora.

W latach dwudziestych XX wieku niejednokrotnie dopuszczano warunkowo do użytku w szkołach podręczniki i pomoce wydane jeszcze przed I wojną światową. Tak było w przypadku Atlasu geograficznego dla szkół średnich Bronisława Gustawicza, wydanego w 1910 roku nakładem autora (skład główny w Księgarni Fabiana Himmelblaua), podręcznika dra Eugeniusza Piaseckiego Zasady wychowania fizycznego. Gry i zabawy ruchowe dla dziatwy i młodzieży (wydanego przez D. E. Friedleina w 1904 roku), Botaniki szkolnej na klasy niższe dra Józefa Rostafińskiego (wydanej w 1916 roku przez G. Gebethnera i Sp.), Modelowania w szkole elementarnej i w domu Stanisława Wójcika (wydanego nakładem autora w 1917 roku) czy llustrowanych dziejów Polski porozbiorowej Kaspra Wojnara z 1916 roku (wyd. 2 uzupełnione ukazało się w serii „Biblioteki im. Tadeusza Kościuszki", nr 10). Atlas Gustawicza po raz ostatni został dopuszczony do użytku w roku szkolnym 1925/26, inne podręczniki wycofano wcześniej.

Ponadto kilka podręczników wydanych zostało nakładem Towarzystwa Szkoły Ludowej. Były to pozycje do nauki śpiewu Franciszka Koniora (Wybór pieśni kościelnych na 2 i 3 głosy dla młodzieży szkolnej. Część pierwsza: Msze i pieśni przygodne, Kraków 1923 i Wybór pieśni kościelnych na 3 głosy dla młodzieży szkolnej. Wydanie drugie uzupełnione. Część druga: Pieśni adwentowe, Kolendy, pieśni postne, pieśni wielkanocne i pieśni przygodne) oraz Katechizm obywatelski dra Mariana Janellego (Kraków 1927).

${ }^{6}$ K. Samsonowska, Spitzer Salomon, [w:] Polski Słownik Biograficzny, Kraków 2002, t. 41, s. $129-131$. 
Bliżej niezidentyfikowane Towarzystwo Wydawnicze opublikowało podręcznik dla klas początkowych pt. Moja książeczka. Nauka czytania i pisania (Dostosowana do potrzeb szkół świętujących Sabat), wydanie 5, Warszawa-Kraków 1920, zaś M. Świeżyński był autorem Pieśni narodowych, które doczekały się 12 wydań. Obie książki to edycje krakowsko-warszawskie o trudnej do ustalenia proweniencji. Jeszcze jednym przykładem kooperacji pomiędzy stołecznymi i krakowskimi wydawcami jest publikacja Konstantego Bzowskiego Nauka o Polsce współczesnej, wyd. 7, Warszawa-Kraków 1928, skład główny u M. Arcta w Warszawie (wyd. 8 - 1929, wyd. 9 - 1930).

Nakładem autora wydana została książka Kazimierza Garbusińskiego Melodie. Podręcznik do nauki śpiewu dla I, Il i III klasy gimnazjalnej oraz seminariów nauczycielskich, Kraków 1925 (wyd. 2 - 1927). Prawdopodobnie również w taki sposób ukazała się praca dra Józefa Rostafińskiego Mały botanik, to jest łatwy sposób oznaczania roślin pospolitych w Polsce, Kraków 1921 (skład gł. w drukarni Uniwersytetu Jagiellońskiego).

Krakowscy wydawcy nie skupiali się wyłącznie na podręcznikach szkolnych, ale podejmowali inicjatywy związane z szeroko rozumianą edukacją, np. wydawali opracowania lektur szkolnych. Przykładem może być znana i popularna seria „Biblioteka Narodowa”, powszechnie kojarzona z Wydawnictwem Zakładu Narodowego im. Ossolińskich. Niejednokrotnie umyka uwadze fakt, że przedsięwzięcie to miało swój początek w Krakowie, gdzie w latach 1919-1930 ukazało się 170 tomików zawierających najwybitniejsze dzieła literatury polskiej i obcej w opracowaniach znakomitych znawców piśmiennictwa?.

Krakowska Spółka Wydawnicza powstała wiosną 1919 roku z inicjatywy profesorów Uniwersytetu Jagiellońskiego oraz ludzi związanych podczas I wojny światowej ze środowiskami legionowymi, przede wszystkim Centralnym Biurem Wydawnictw Naczelnego Komitetu Narodowego. Nowa oficyna wydawnicza przybrała formę spółki akcyjnej. Jednym z ważniejszych akcjonariuszy był dr Adam Muszyński, zarazem dyrektor administracyjny wydawnictwa ${ }^{8}$. Radę Nadzorczą tworzyli: prof. Stanisław Estreicher, prof. Stanisław Kot, prof. Tadeusz Sinko, dr Józef Muczkowski i rejent Tadeusz Starzewski jako jej przewodniczący ${ }^{9}$. Zastępcą dyrektora przez cały okres funkcjonowania firmy był Kazimierz Giebułtowski, odpowiedzialny za sprawy redakcyjne. Wydawnictwo rozpoczęło działalność, mając mocne zaplecze finansowe i materialne. Siedziba firmy mieściła się w domu Włodków przy ul. św. Filipa 25, zaś w 1922 bądź 1923 roku przy ul. Wiślnej 3 otwarto we współpracy z warszawską firmą Michała Arcta własną księgarnię pod szyldem Księgarni Jagiellońskiej. Dzięki osobistym kontaktom dyrektora Muszyńskiego z prof. Jerzym Michalskim, ministrem skarbu w latach 1921-1922, Wydawnictwo uzyskało znaczne przydziały papieru w dobrych gatunkach (trzeba

7 Wykaz tytułów „Biblioteki Narodowej” wydanych przez Krakowską Spółkę Wydawnicza zawiera Aneks 1.

${ }^{8}$ A. Słapa, Oczami księgarza, [w:] Cyganeria i polityka. Wspomnienia krakowskie 1919-1939, Warszawa 1964, s. 7.

9 F. Bielak, Ambitna „Biblioteka” i jej redaktor, [w:] Almanach Biblioteki Narodowej. W pięćdziesięciolecie wydawnictwa 1919-1969, Wrocław-Warszawa-Kraków 1969, s. 16; M. Brahmer, Z pierwszych lat, [w:] tamże, s. 23. 
tu dodać, że moce produkcyjne polskich papierni, z reguły przestarzałych, były niewielkie, a w asortymencie dominował papier drzewny, często gorszy od gazetowego). Zapasy deficytowego papieru stanowiły ponadto doskonałą lokatę w okresie postępującej inflacji i dewaluacji marki polskiej ${ }^{10}$. Dyrektor Muszyński, z wykształcenia prawnik, dopiero z biegiem czasu nabierał doświadczenia w sprawach wydawniczych, dlatego sprawy redakcyjne scedował na swojego zastępcę - Kazimierza Giebułtowskiego ${ }^{11}$. Dał się natomiast poznać już wcześniej jako doskonały organizator i menedżer, wierzono zatem, że i na tym stanowisku świetnie sobie poradzi. Dobre wyniki finansowe osiągane w pierwszych latach działalności firmy ugruntowały pozycję Muszyńskiego i przyczyniły się do pozyskania nowych akcjonariuszy. W każdym razie początkowy okres obecności firmy na rynku wydawniczym był niezwykle owocny. Tym większym zaskoczeniem było zawieszenie działalności spółki w roku 1930, a następnie jej likwidacja cztery lata później ${ }^{12}$. Trudno dziś, z perspektywy lat, ustalić, co było przyczyną upadku firmy. Na pewno, co potwierdzają wspomnienia księgarza Aleksandra Słapy, nie były tego powodem nieporozumienia między udziałowcami. Niewątpliwie istotną rolę odegrał ogólnoświatowy kryzys gospodarczy z końca lat dwudziestych XX wieku, ale też nadmierna pewność siebie i wiara we własne siły kierującego firmą A. Muszyńskiego ${ }^{13}$. W 1929 roku, z okazji 10-lecia serii „Biblioteki Narodowej” ukazał się Almanach Biblioteki Narodowej i nie było to bynajmniej pożegnanie z tym wydawnictwem. Planowano dalszy rozwój w następnych latach.

Likwidację spółki prowadził wicedyrektor K. Giebułtowski (Muszyński wycofał się pod pretekstem choroby, a następnie powrócił do zawodu prawniczego, prowadząc kolejno praktykę notarialną w Łodzi, Brześciu n. Bugiem, Warszawie i Wyszkowie) ${ }^{14}$. Z pracy w Radzie Nadzorczej zrezygnował też Józef Muczkowski.

Krakowska Spółka Wydawnicza specjalizowała się w seriach wydawniczych, były to: „Z historii i literatury”, „Biblioteka historyczna”, „Państwa współczesne” oraz „Teksty źródłowe do nauki historii w szkole średniej”. O tej ostatniej serii będzie jeszcze mowa w dalszej części artykułu. Oficyna wydawała też cieszące się powodzeniem u czytelników powieści Zofii Kossak o tematyce historycznej ${ }^{15}$ oraz prace Aleksandra Brücknera: Słownik etymologiczny języka polskiego ${ }^{16}$ i Dzieje kultury polskiej ${ }^{17}$.

10 F. Bielak, Ambitna „Biblioteka”..., s. 16.

11 O Giebułtowskim jako redaktorze „Biblioteki Narodowej” pisali w samych superlatywach wybitni historycy literatury: Stanisław Pigoń i Julian Krzyżanowski, zob. Almanach Biblioteki Narodowej. W pięćdziesięciolecie wydawnictwa 1919-1969, Wrocław-Warszawa-Kraków 1969, passim; słów uznania nie szczędził mu również Ignacy Chrzanowski, zob. tenże, Biblioteka Narodowa, [w:] Almanach Biblioteki Narodowej. W dziesięciolecie wydawnictwa 1919-1929, Kraków 1929, s. 15. Zob. też. M. Szawłowska, Giebułtowski Kazimierz, [w:] Słownik Pracowników Książki Polskiej, Warszawa-Łódź 1972, s. 257.

12 A. Słapa, Oczami księgarza..., s. 7.

13 Tamże, s. 8-9.

14 J. Hulewicz, Muszyński Adam, [w:] Polski Słownik Biograficzny, t. 22, Wrocław 1976, s. 301-302.

15 Pożoga (1922, 2 wyd. - 1923, 4 wyd. - 1927), Beatum scelus (1924, 2 wyd. - 1927), Szaleńcy Boży (1929, 2 wyd. - 1930), Złota wolność (1928, 2 wyd. - 1929), Legnickie pole (1930).

16 Słownik (2 tomy) ukazywał się w zeszytach od marca 1926 do kwietnia 1927 r.

17 Tom 1 (1930), tom 2 (1930), tom 3 (1931); tom 4 ukazał się już po wojnie nakładem Wydawnictwa F. Pieczątkowski i Ska (Kraków-Warszawa 1946). 
Największym jednak osiągnięciem Krakowskiej Spółki Wydawniczej była bez wątpienia seria „Biblioteka Narodowa”. Jej zamysł pojawił się w czasie I wojny światowej, gdy uświadomiono sobie, ,jak mało w warstwie inteligentnej narodu znany jest dorobek kultury własnej przeszłości”18. Spiritus movens całego przedsięwzięcia był historyk literatury, profesor Stanisław Kot. To on opracował program i zasady wydawnicze nowej serii, której celem było „zaspokoić pilną potrzebę kulturalną i przynieść zarówno dla każdego inteligentnego Polaka jak i dla kształcącej się młodzieży [...] wszystkie celniejsze utwory poezji i prozy polskiej od wieku XVI aż po dobę spółczesną, uwzględniając nie tylko poetów i beletrystów, ale także mówców, historyków i filozofów"19. Seria miała stanowić lekturę uzupełniającą dla klas wyższych szkół średnich i dla studentów uniwersytetów. Ukazywały się dwie serie „Biblioteki Narodowej”: seria I - obejmująca dzieła literatury polskiej i seria II - prezentująca utwory literatury powszechnej.

Pierwszy tomik serii ujrzał światło dzienne 1 listopada 1919 roku. Były to Treny Jana Kochanowskiego w opracowaniu Tadeusza Sinki. Drugą serię zainicjowała Antygona Sofoklesa w przekładzie i opracowaniu Kazimierza Morawskiego (1920). Pod egidą Krakowskiej Spółki Wydawniczej ukazało się 170 tomików: 118 tomików I serii (średnio 28 rocznie) oraz 52 tomiki II serii. Przeciętny nakład wynosił 10 000-12 000 egzemplarzy, najniższy 6000 egz. Zdarzały się jednak edycje o wyjątkowo wysokich nakładach sięgających 30000 , a nawet 40000 egz. Najwyższy nakład osiągnęły Treny Kochanowskiego (70 000 egzemplarzy).

Wśród dzieł ukazujących się w I serii można wyróżnić kilka grup, biorąc pod uwagę kryterium chronologiczne. Najwięcej tomików prezentowało literaturę XIX-wieczną (ok. 70\%, dzieła Mickiewicza, Słowackiego, Fredry), dalej utwory staropolskie do XVI wieku włącznie (12\%, przede wszystkim dzieła Kochanowskiego). Literatura XVIII wieku stanowiła ok. 11\% całości (Niemcewicz, Konarski, Trembecki), a około 6\% reprezentowało utwory XVII-wieczne (Potocki, Pasek)20.

W serii II najliczniejsze były tomiki z utworami literatury do XVI wieku włącznie (ok. 47\%), z przewagą autorów antycznych - było ich 20, przede wszystkim o charakterze lekturowym (Sofokles, Ajschylos, Homer, Wergiliusz, Eurypides, Plutarch, Arystofanes, Plaut, Horacy). Literatura XVIl-wieczna, głównie utwory Szekspira i Moliera, stanowiła 28\% tomików. Pozostałe tomy obejmowały literaturę z XVIII i XIX wieku²1.

Warto nadmienić, że rozważano utworzenie trzeciej serii, prezentującej wydania nieliterackie (historyczne, retoryczne oraz pedagogiczne), ale ostatecznie pomysł ten zarzucono.

W latach 1932-1933, z powodu trwającej likwidacji spółki, wstrzymano wydawanie „Biblioteki Narodowej”. Pomysłodawca serii, prof. Stanisław Kot, podejmował

18 Od Wydawnictwa, [w:] Almanach Biblioteki Narodowej. W dziesięciolecie wydawnictwa 1919-1929, Kraków 1929, s. 1.

19 F. Bielak, Ambitna „Biblioteka”..., s. 9.

${ }_{20}$ M. Golenia, Przyczynek do historii Krakowskiej Spółki Wydawniczej, praca magisterska napisana pod kierunkiem Jerzego Jarowieckiego w Samodzielnym Zakładzie Bibliotekoznawstwa i Informacji Naukowej, WSP, Kraków 1983, s. 22.

21 Tamże. 
usilne zabiegi w celu uratowania tej cennej dla kultury narodowej inicjatywy. Rozpisano konkurs na sprzedaż całego zapasu „Biblioteki Narodowej” i innych wydawnictw z prawem do dalszych wydań. Podjęto rozmowy z dyrektorem Wydawnictwa "Ossolineum" Antonim Lewakiem, uwieńczone podpisaniem umowy kupna serii przez Zakład Narodowy im. Ossolińskich we Lwowie w dniu 22 lipca 1933 roku. Wartość transakcji - ustalona przez rzeczoznawców sądowych, dra Aleksandra Słapę i Mariana Krzyżanowskiego 22 - wyniosła 57618 zł. Na mocy umowy nabywca otrzymał prawo używania nazwy serii oraz wszedł w prawa autorskie i nakładowe zarówno do dzieł już wydanych, jak i tych, które miały się ukazać w przyszłości. Ossolineum przejęło również rękopisy, wszelkie materiały już wydrukowane, a także klisze i matryce drukarskie ${ }^{23}$.

Druga serią „do użytku szkolnego” w ofercie Krakowskiej Spółki Wydawniczej były „Teksty źródłowe do nauki historii w szkole średniej”. Inicjatorem i redaktorem serii był, podobnie jak w przypadku „Biblioteki Narodowej”, prof. Stanisław Kot. Całość obejmowała 60 zeszytów, które ukazywały się od 1923 do 1928 roku (większość w latach 1923-1924). Wśród autorów opracowujących poszczególne tomiki można wymienić tak znakomitych historyków, jak: Władysław Semkowicz, Roman Grodecki, Jan Ptaśnik, Fryderyk Papée, Ludwik Finkel, Władysław Pociecha, Władysław Konopczyński, Stanisław Kutrzeba i in. Zeszyty miały jednakowy format $8^{\circ}$ oraz objętość 32 stron ( 2 arkusze). Oprawiano je w charakterystyczny dla Krakowskiej Spółki Wydawniczej jasnoniebieski, cienki karton ${ }^{24}$.

Teksty zamieszczane w zeszytach były wyborem materiałów źródłowych przydatnych w nauce historii, poczynając od starożytnego Egiptu aż po historię najnowszą. Zaopatrzone były w aparat pomocniczy w postaci przypisów o charakterze bibliograficznym, słownikowym oraz rzeczowym - przynosiły wyjaśnienia trudniejszych pojęć, nazw, dat i faktów. Stanowiły dodatkową pomoc w nauce historii, rozszerzając materiał i przynosząc nowe informacje uczniom, którzy szczególnie interesowali się tym przedmiotem ${ }^{25}$.

Wśród krakowskich firm wydawniczych podejmujących inicjatywy na rzecz szkolnictwa i edukacji na szczególną uwagę zasługują dwie oficyny działające w różnych obszarach wspomnianego kręgu szeroko rozumianej edukacji. $Z$ jednej strony Księgarnia Geograficzna „Orbis”, wydająca podręczniki i pomoce szkolne z zakresu geografii, z powodzeniem konkurująca na rynku z renomowanymi warszawskimi i lwowskimi oficynami. Jej książki przez całe lata dwudzieste ubiegłego stulecia cieszyły się uznaniem i powodzeniem czytelniczym, czego dowodem są

${ }^{22}$ Aleksander Słapa (1895-1964) był w latach 1918-1950 (z czteroletnią przerwą w okresie okupacji hitlerowskiej) kierownikiem księgarni Gebethnera i S-ki w Krakowie, natomiast Marian Krzyżanowski (1880-1964) był od 1908 do 1950 roku właścicielem Księgarni S.A. Krzyżanowski w Krakowie.

${ }^{23}$ W. Kocyba-Kamińska, Oficyna Ossolińska w latach 1920-1939, Wrocław 1973, s. 194.

${ }^{24}$ M. Golenia, Przyczynek do historii..., s. 33.

${ }^{25}$ Spis zeszytów serii zawiera Aneks 2 do niniejszego artykułu. 
kolejne wznowienia tytułów sięgające ponad dwudziestu edycji. Na drugim biegunie znajduje się Krakowska Spółka Wydawnicza, która zainicjowała trwający po dziś dzień fenomen serii do użytku szkolnego, a mianowicie „Biblioteki Narodowej". Sukces i popularność zarówno tej, jak i innych serii wydawniczych, sprawiły, że pomimo upadku wydawnictwa znaleziono kontynuatora cyklu, który za kila lat będzie obchodzić stulecie obecności na rynku.

Nie można też zapominać o mniejszych wydawcach, często dziś zapomnianych, którzy również odegrali swoją rolę w dziele służby na rzecz szkoły, wreszcie o wcale licznych wydawcach nieinstytucjonalnych - autorach wydających podręczniki i książki szkolne własnym nakładem. Wszystkie te osoby i instytucje tworzą barwną historię ruchu wydawniczego Drugiej Rzeczypospolitej. 


\title{
Aneks 1
}

\section{Biblioteka Narodowa}

\author{
Seria I
}

Anczyc W. L., Kościuszko pod Racławicami i poezje patriotyczne. Opracował J. S. Bystroń, (nr 69) 1924

Anczyc W. L., Obrazki dramatyczne ludowe. Opracował J. S. Bystroń, (nr 78) 1924

Anonim tzw. Gall, Kronika polska. Przełożył i opracował R. Grodecki, (nr 59) 1923

Asnyk A., Wybór poezji. Wstępem i objaśnieniami zaopatrzył E. Kucharski, (nr 67) 1924

Bałucki M., Grube ryby. Komedia w trzech aktach. Opracował Z. Tempka-Nowakowski, (nr 95) 1926

Bliziński J., Pan Damazy. Komedia konkursowa w czterech aktach. Opracował Z. Tempka-Nowakowski, (nr 38) 1921

Brodziński K., Mowy i pisma patriotyczne oraz O powołaniu i obowiązkach młodzieży akademickiej. Opracował I. Chrzanowski, (nr 94) 1926

Brodziński K., O klasyczności i romantyczności tudzież o duchu poezji polskiej. Z wstępem i objaśnieniami A. Łuckiego, (nr 10) 1920

Brodziński K., Wspomnienia mojej młodości i inne pisma autobiograficzne. Wstępem i objaśnieniami zaopatrzył A. Łucki, (nr 113) 1928

Brodziński K., Wybór pism. W opracowaniu A. Łuckiego, (nr 34) 1921

Czajkowski M., Owruczanin. Powieść historyczna z 1812 roku. Opracował Z. Szweykowski, (nr 103) 1927

Z ks. Czartoryskich M. ks. Wirtemberska, Malwina czyli domyślność serca. Z wstępem i objaśnieniami K. Wojciechowskiego, (nr 23) 1920

Czasy saskie. Wybór źródeł. Wstępem i objaśnieniami zaopatrzył J. Feldman, (nr 110) 1928

Długosz J., Bitwa grunwaldzka (z „Historii Polski”). Opracował J. Dąbrowski, (nr 31) 1921

Feliński A., Barbara Radziwiłłówna. Tragedia w pięciu aktach. Z wstępem i objaśnieniami M. Szyjkowskiego, (nr 9) 1920

Fredro A., Cudzoziemszczyzna. Komedia we trzech aktach. Opracował St. Windakiewicz, (nr 97) 1927

Fredro A., Dożywocie. Komedia we trzech aktach wierszem. Opracował St. Windakiewicz, (nr 93) 1927

Fredro A., Pan Jowialski. Opracował E. Kucharski, (nr 36) 1921

Fredro A., Śluby panieńskie. Opracował E. Kucharski, (nr 22) 1920

Fredro A., Zemsta. Komedia w czterech aktach wierszem. Opracował E. Kucharski, (nr 32) 1921

Goszczyński S., Król Zamczyska. Opracował J. Tretiak, (nr 50) 1922

Goszczyński S., Zamek Kaniowski. Powieść. Opracował J. Tretiak, (nr 44) 1921

Górnicki Ł., Dworzanin polski. Opracował R. Pollak, (nr 109) 1928

Kaczkowski Z., Murdelio. Powieść. Opracował Z. Szweykowski, (nr 84) 1925

Karpiński F., Wybór poezji. Opracował Wł. Jankowski, (nr 89) 1926

Kasprowicz J., Wybór poezji. Opracował S. Kołaczkowski, (nr 120) 1929

Kitowicz J., Opis obyczajów i zwyczajów za panowania Augusta III. Wstępem i objaśnieniami zaopatrzył M. Janik, (nr 88) 1925

Kochanowski J., Odprawa posłów greckich. Z wstępem i komentarzem T. Sinki, (nr 3) 1919

Kochanowski J., Pieśni i wybór innych wierszy. Opracował T. Sinko, (nr 100) 1927

Kochanowski J., Treny. Z wstępem i komentarzem T. Sinki, (nr I) 1919

Kochowski W., Psalmodia polska oraz wybór liryków i fraszek. Wydał i objaśnił J. Krzyżanowski, (nr 92) 1926 
Konarski St., Wybór pism politycznych. Z wstępem i objaśnieniami W. Konopczyńskiego, (nr 35) 1921 Konfederacja barska. Wybór tekstów. Wstępem i objaśnieniami zaopatrzył W. Konopczyński, (nr 102) 1928

Kopernik M., Wybór pism w przekładzie polskim. Opracował A. Birkenmajer, (nr 15) 1920

Korzeniowski J., Karpaccy górale. Dramat w trzech aktach. Wstępem i objaśnieniami zaopatrzył W. Hahn, (nr 63) 1923

Korzeniowski J., Kolokacja. Opracował K. Wojciechowski, (nr 28) 1925

Korzeniowski J., Spekulant. Z wstępem i objaśnieniami K. Wojciechowskiego, (nr 25) 1921

Krasicki I., Mikołaja Doświadczyńskiego przypadki. Z autografu wydał, wstępem i objaśnieniami zaopatrzył B. Gubrynowicz, (nr 41) 1921

Krasicki I., Pan Podstoli. Opracował J. Krzyżanowski, (nr 101) 1927

Krasiński Z., Irydion. Z wstępem i objaśnieniami T. Sinki, (nr 42) 1921

Krasiński Z., Nie-Boska Komedia. Opracował J. Kleiner, (nr 24) 1920

Krasiński Z., Przedświt. Opracował J. Kleiner, (nr 18) 1922

Krasiński Z., Psalmy przyszłości oraz J. Słowackiego Odpowiedź na „Psalmy Przyszłości”. Opracował M. Kridl, (nr 107) 1928

Kraszewski J. I., Brühl. Opowiadanie historyczne. Opracował J. Feldman, (nr 114) 1928

Kraszewski J. I., Budzik. Obrazek. Ze wstępem i objaśnieniami W. Hahna, (nr 55) 1923

Kraszewski J. I., Historia o Janaszu Korczaku i o pięknej miecznikównie. Powieść z czasów Jana Sobieskiego. Wstępem i objaśnieniami zaopatrzył W. Hahn, (nr 81) 1924

Kraszewski J. I., Morituri. Powieść. Wstępem o życiu i twórczości J. I. Kraszewskiego poprzedził W. Hahn, (nr 86) 1925

Kraszewski J. I. Powrót do gniazda. Powieść z podań XVI wieku. W opracowaniu W. Hahna, (nr 58) 1923

Kraszewski J. I. Stara baśń. Powieść z IX wieku. Wstępem i objaśnieniami zaopatrzył K. Wojciechowski, (nr 53) 1922

Kraszewski J. I., Zygmuntowskie czasy. Powieść z roku 1572. Opracował A. Bar, (nr 91) 1926

Łoziński W., Zaklęty dwór. Powieść w dwóch częściach. Opracował A. Bar, (nr 96) 1926

Malczewski A., Maria. Powieść ukraińska. Podług autografu wydał, wstępem i objaśnieniami zaopatrzył J. Ujejski, (nr 46) 1922

Mickiewicz A., Dziady, część trzecia. Opracował J. Kallenbach, (nr 20) 1920

Mickiewicz A., Dziady wileńskie. Z wstępem i objaśnieniami J. Kallenbacha, (nr 11) 1920

Mickiewicz A., Grażyna. Powieść litewska. Z wstępem J. Tretiaka i objaśnieniami H. Życzyńskiego, (nr 74) 1924

Mickiewicz A., Konrad Wallenrod. Opracował J. Ujejski, (nr 72) 1924

Mickiewicz A., Księgi narodu polskiego i pielgrzymstwa polskiego. Opracował St. Pigoń, (nr 17) 1920

Mickiewicz A., Pan Tadeusz. Historia szlachecka z roku 1811 i 1812. Opracował St. Pigoń, (nr 83) 1925

Mickiewicz A., Pisma estetyczno-krytyczne. Opracował H. Życzyński, (nr 79) 1924

Mickiewicz A., Poezje. Tom I. (Wiersze młodzieńcze - Ballady - Grażyna). Wybór, wstęp i objaśnienia J. Kallenbacha, (nr 6) 1920

Mickiewicz A., Poezje. Tom II (Wiersze z lat 1825-1855). (Pieśni - Sonety - Poezje patriotyczne, religijne i filozoficzne - Wiersze okolicznościowe - Bajki). Wstęp i układ J. Kallenbacha. Objaśnieniami zaopatrzył J. Bystrzycki, (nr 66) 1924

Mickiewicz A., Trybuna Ludów. Przekład, wstęp i komentarz E. Haeckera, (nr 27) 1921

Mochnacki M., O literaturze polskiej w wieku dziewiętnastym. Opracował H. Życzyński, (nr 56) 1923

Najdawniejsze zabytki języka polskiego. Opracował W. Taszycki, (nr 104) 1927

Niemcewicz J., Powrót posła. Komedia w trzech aktach oraz Wybór bajek politycznych z epoki Sejmu Wielkiego. Z wstępem i objaśnieniami St. Kota, (nr 4) 1919

Norwid C., Wybór poezji. Opracował St. Cywiński, (nr 64) 1924

Pasek J. Ch., Pamiętniki. Wstępem i objaśnieniami zaopatrzył A. Brückner, (nr 52) 1924

Poezja barska. Zebrał, wstępem i objaśnieniami zaopatrzył K. Kolbuszewski, (nr 108) 1928

Pol W., Mohort. Wstępem i objaśnieniami zaopatrzył A. Łucki, (nr 52) 1922

Pol W., Pieśni Janusza. Z wstępem i objaśnieniami J. Kallenbacha, (nr 33) 1921

Pol W., Pieśń o ziemi naszej oraz liryki wybrane. Z wstępem i objaśnieniami R. Zawilińskiego, (nr 2l) 1920 
Polska pieśń ludowa. Wybór. Opracował J. St. Bystroń, (nr 26) 1921

Polska proza średniowieczna. Wybrał i objaśnił A. Brückner, (nr 68) 1923

Potocki W., Wiersze wybrane. Objaśnił A. Brückner, (nr 19) 1920

Potocki W., Wojna Chocimska. Z autografu wydał i opracował A. Brückner, (nr 75) 1924

Rej M., Pisma prozą i wierszem. Wybrał i objaśnił A. Brückner, (nr 40) 1921

Romanowski R., Dziewczę z Sącza oraz Wybór liryków. Wstępem i objaśnieniami opatrzył St. Lam, (nr 39) 1921

Rzewuski H., Listopad. Romans historyczny z drugiej połowy wieku XVIII. Wstępem i objaśnieniami zaopatrzył K. Wojciechowski, (nr 61) 1923

Rzewuski H., Pamiątki Soplicy. Z autografu wydał i opracował Z. Szweykowski, (nr 112) 1928

Sęp Szarzyński M., Rytmy oraz anonimowe pieśni i listy miłosne z XVI w. Opracował T. Sinko, (nr 118) 1928

Sielanka polska XVII wieku. Szymon Simonides - Bartłomiej Zimorowic - Jan Gawiński. Wybrał i objaśnił A. Brückner, (nr 48) 1922

Skarga P., Kazania sejmowe. Opracował St. Kot, (nr 70) 1925

Słowacki J., Anhelli. Z wstępem i objaśnieniami J. Ujejskiego, (nr 7) 1919

Słowacki J., Balladyna. Tragedia w pięciu aktach. Opracował J. Kleiner, (nr 51) 1922

Słowacki J., Beniowski. Poema. Pięć pierwszych pieśni. Opracował J. Kleiner, (nr 13) 1921

Słowacki J., Beniowski. Wydanie całkowite w nowym układzie. Opracował J. Kleiner, (nr 13/14) 1922

Słowacki J., Fantazy czyli Nowa Dejanira. Opracował S. Kołaczkowski, (nr 105) 1927

Słowacki J., Kordian. Z wstępem i objaśnieniami J. Ujejskiego, (nr 2) 1919

Słowacki J., Ksiądz Marek. Poema dramatyczne w trzech aktach. Z wstępem i objaśnieniami St. Turowskiego, (nr 29) 1921

Słowacki J., Lilia Weneda. Tragedia w pięciu aktach. Wstępem i objaśnieniami zaopatrzył M. Janik, (nr 16) 1920

Słowacki J., Maria Stuart. Drama historyczne w pięciu aktach. Opracował J. Ujejski, (nr 111) 1928

Słowacki J., Mazepa. Tragedia w pięciu aktach. Wstępem i objaśnieniami zaopatrzył B. Gubrynowicz, (nr 76) 1924

Słowacki J., Mindowe, król litewski. Obraz historyczny w pięciu aktach. Z wstępem i objaśnieniami W. Hahna, (nr 43) 1921

Słowacki J., Powieści poetyckie. Opracował M. Kridl, (nr 47) 1921

Słowacki J., Sen srebrny Salomei. Romans dramatyczny w pięciu aktach. Wstępem i objaśnieniami zaopatrzył St. Turowski, (nr 57) 1923

Słowacki J., Trzy poemata. Wydał i objaśnił J. Maurer, (nr 49) 1922

Sonet polski. Wybór tekstów. Wstępem i objaśnieniami zaopatrzył Wł. Folkierski, (nr 82) 1925

Sowiński L., Wybór poezji. Opracował Wł. Bryda, (nr 45) 1922

Staszic St., Przestrogi dla Polski. Wydanie krytyczne przygotował i opracował S. Czarnowski, (nr 98) 1926

Staszic St., Uwagi nad życiem Jana Zamoyskiego. Wydanie krytyczne przygotował i wstępem zaopatrzył S. Czarnowski, (nr 90) 1926

Syrokomla Wł. (L. Wł. Kondratowicz), Wybór poezji. Opracował P. Bielak, (nr 54) 1922

Średniowieczna pieśń religijna polska. Wydał A. Brückner, (nr 65) 1923

Średniowieczna poezja polska świecka. Zebrał i opracował S. Vrtel-Wierczyński, (nr 60) 1923

Tańska K., Dziennik Franciszki Krasińskiej, w ostatnich latach panowania Augusta III pisany. Opracowała I. Kotowa, (nr 119) 1929

Tańska K., Listy Elżbiety Rzeczyckiej oraz Nocleg w Kromołowie i Obiady czwartkowe. Opracowała I. Kotowa, (nr 99) 1927

Towarzystwo Filomatów. Wybór tekstów. Wstęp i objaśnienia A. Łuckiego, (nr 77) 1924

Towiański A., Wybór pism i nauk. Opracował St. Pigoń, (nr 8) 1920

Trembecki St., Sofiówka i Wybór poezji. Opracował Wł. Jankowski, (nr 80) 1925

Twardowski S., Nadobna Paskwalina. Wstępem i objaśnieniami zaopatrzył R. Pollak, (nr 87) 1926

Ujejski K., Wybór poezji. Opracował M. Janik, (nr 37) 1921

Wasilewski E., Poezje. Wstępem i objaśnieniami zaopatrzył E. Haecker, (nr 85) 1925

Wybicki J., Życie moje oraz Wspomnienie o Andrzeju i Konstancji Zamoyskich. Z autografów wydał i objaśnił A. M. Skałkowski, (nr 106) 1927 
Zabłocki F., Sarmatyzm. Komedia w pięciu aktach. Tekst ustalił, wstępem i objaśnieniami zaopatrzył L. Bernacki, (nr 115) 1928

Zaleski B., Wybór poezji. Opracował J. Tretiak, (nr 30) 1921

Zimorowic Sz., Roksolanki. Opracował A. Brückner, (nr 73) 1924

Żmichowska N., Poganka. Opracował T. Żeleński (Boy), (nr 12I) 1930

Żółkiewski St., Początek i progres wojny moskiewskiej. Z wstępem i komentarzem W. Sobieskiego, (nr 12) 1920

\section{Seria II}

Aischylos, Persowie. Przełożył K. Kaszewski. Wstępem i objaśnieniem zaopatrzył St. Witkowski, (nr 19) 1922

Aischylos, Prometeusz skowany. Przełożył J. Kasprowicz. Wstępem i objaśnieniami zaopatrzył St. Witkowski, (nr 7) 1921

Antologia literatury francuskiej. Z własnych przekładów ułożył i opracował T. Żeleński (Boy), (nr 18) 1922

Arystofanes, Chmury. Przełożył i przypisami zaopatrzył B. Butrymowicz. Ze wstępem J. Kowalskiego, (nr 27) 1923

Arystofanes, Ptaki. Przełożył i uwagami zaopatrzył B. Butrymowicz. Ze wstępem K. Morawskiego, (nr 23) 1922

Arystofanes, Rycerze. Przełożył i opracował B. Butrymowicz, (nr 11) 1922

Św. Augustyn, Wyznania. Przełożyła K. Wisłocka-Remerowa. Opracował J. Kowalski, (nr 45) 1929

Byron G. G., Manfred, Kain. Przełożyła Z. Reutt-Witkowska. Wstępem i objaśnieniami zaopatrzył A. Tretiak, (nr 54) 1928

Byron G. G., Powieści poetyckie. Opracował A. Tretiak, (nr 34) 1924

Calderon de la Barca Pedro, Książę Niezłomny. Tragedia w trzech aktach. W przekładzie J. Słowackiego. Wstępem i objaśnieniami zaopatrzył Wł. Folkierski, (nr 55) 1930

Corneille P., Cyd. Tragedia w pięciu aktach. W tłumaczeniu J. A. Morsztyna. Opracował Wł. Folkierski, (nr 8) 1921

Demostenes, Wybór mów. Przełożył, wstępem i objaśnieniami zaopatrzył J. Kowalski, (nr 15) 1922

Eurypides, Hippolitos (Fedra). W przekładzie B. Butrymowicza. Wstępem i objaśnieniami zaopatrzył S. Hammer, (nr 41) 1928

Eurypides, Medea. Przełożył, wstępem i objaśnieniami zaopatrzył B. Butrymowicz, (nr 13) 1922

Goethe J. W., Cierpienia młodego Wertera. Przełożył F. Mirandola. Opracował Z. Zagórowski, (nr 22) 1922

Goethe J. W., Herman i Dorota. Przełożył L. Jenike. Opracował Z. Zagórowski, (nr 51) 1920

Homer, Iliada. W przekładzie F. K. Dmochowskiego. Wstępem i komentarzem opatrzył T. Sinko, (nr 17) 1922

Homer, Odyseja. W przekładzie L. Siemieńskiego. Wstępem i objaśnieniami zaopatrzył T. Sinko, (nr 21) 1922

Horacy, Wybór poezji. Przełożył i opracował J. Zawirowski, (nr 25) 1923

Ksenofont, Sympozjon oraz wybór pism. Przełożył i opracował A. Rapaport, (nr 39) 1929

Ksenofont, Wyprawa Cyrusa (Anabaza). Przełożył i przypisami zaopatrzył A. Rapaport. Z wstępem St. Witkowskiego, (nr 31) 1924

La Rochefoucauld, Maksymy i rozważania moralne. Przełożył, wstępem i objaśnieniami zaopatrzył T. Żeleński (Boy), (nr 38) 1925

Molier, Mieszczanin szlachcicem. Komedia w pięciu aktach z baletem. Przełożył i opracował T. Żeleński (Boy), (nr 10) 1921

Molier, Mizantrop. Komedia w pięciu aktach. Przełożył i opracował T. Żeleński (Boy), (nr 2) 1920

Molier, Pocieszne wykwintnisie. Komedia. Przełożył, wstępem i objaśnieniami zaopatrzył T. Boy-Żeleński, (nr 43) 1926

Molier, Skąpiec. Komedia w pięciu aktach. Przełożył i opracował T. Żeleński (Boy), (nr 6) 1921 
Molier, Świętoszek (Tartufe). Komedia w pięciu aktach. Przełożył i opracował T. Żeleński (Boy), (nr 40) 1925

Plautus T. M., Bracia. Przełożył i opracował G. Przychocki, (nr 33) 1924

Plautus T. M., Kupiec. Przełożył i opracował G. Przychocki, (nr 46) 1927

Plautus T. M., Żołnierz Samochwał. Przełożył i opracował G. Przychocki, (nr 53) 1929

Plutarch z Cheronei, Żywoty sławnych mężów. W zrewidowanym przekładzie F. N. Golańskiego, z dodatkiem trzech żywotów w przeróbce I. Krasickiego. Z wstępem i uwagami T. Sinki, (nr 3) 1921

Puszkin A., Eugeniusz Oniegin. Romans wierszem. W przekładzie L. Belmonta. Opracował, wstępem i przypisami zaopatrzył W. Lednicki, (nr 35) 1925

Rousseau J. J., O umowie społecznej. Przełożył i opracował M. Starzewski, (nr 44) 1927

Rousseau J. J., Uwagi nad rządem Polski. Przełożył i opracował M. Starzewski, (nr 32) 1924

Schiller F., Dziewica Orleańska. Tragedia romantyczna w pięciu aktach z prologiem. Przełożył F. Mirandola. Opracował Z. Żygulski, (nr 47) 1928

Schiller F., Zbójcy. Dramat w pięciu aktach. W przekładzie M. Budzyńskiego. Wstępem i przypisami zaopatrzył Z. Żygulski, (nr 30) 1923

Scott W., Waverley. Przekład T. Świderskiej. Wstępem zaopatrzył i opracował A. Tretiak, (nr 56) 1929

Słowo o wyprawie lgora. Przełożył J. Tuwim. Wstępem i objaśnieniami zaopatrzył A. Brückner, (nr 50) 1928

Sofokles, Antygona. Przetłumaczył i opracował K. Morawski, (nr I) 1920

Sofokles, Elektra. Przełożył i opracował K. Morawski, (nr 9) 1921

Sofokles, Król Edyp. Przełożył i opracował K. Morawski, (nr 5) 1921

Szekspir W., Antoniusz i Kleopatra. Tragedia w pięciu aktach. Przełożył oraz wstępem i objaśnieniami opatrzył Wł. Tarnawski, (nr 14) 1921

Szekspir W., Burza. Komedia w pięciu aktach. W tłumaczeniu J. Paszkowskiego. Opracował A. Tretiak, (nr 12) 1921

Szekspir W., Hamlet. Tragedia w pięciu aktach. Przełożył oraz wstępem i objaśnieniami opatrzył A. Tretiak, (nr 20) 1922

Szekspir W., Juliusz Cezar. Tragedia w pięciu aktach. Przełożył oraz wstępem i objaśnieniami opatrzył Wł. Tarnawski, (nr 36) 1925

Szekspir W., Król Lear. Tragedia w pięciu aktach. Przełożył oraz wstępem i objaśnieniami opatrzył A. Tretiak, (nr 28) 1923

Szekspir W., Makbet. Tragedia w pięciu aktach. W tłumaczeniu J. Paszkowskiego. Wstępem i objaśnieniami zaopatrzył A. Tretiak, (nr 16) 1921

Szekspir W., Otello. Tragedia w pięciu aktach. W przekładzie J. Paszkowskiego. Opracował A. Tretiak, (nr 42) 1927

Szekspir W., Romeo i Julia. Tragedia w pięciu aktach. Przełożył oraz wstępem i objaśnieniami opatrzył Wł. Tarnawski, (nr 26) 1924

Tasso T., Goffred abo Jeruzalem wyzwolona. W przekładzie P. Kochanowskiego. Opracował R. Pollak, (nr 4) 1921

Wergiliusz, Eneida. W przekładzie Ks. T. Karyłowskiego. Z wstępem i objaśnieniami T. Sinki, (nr 29) 1924

Wybór listów francuskich XVII i XVIII wieku. Przełożył i opracował M. M. Paciorkiewicz, (nr 24) 1923 


\section{Aneks 2}

\section{Teksty źródłowe do nauki historii w szkole średniej}

$\mathrm{Nr}$ 1. Egipt starożytny. Opracował dr A. Śmieszek

$\mathrm{Nr}$ 2. Asyria i Babilon. Opracował dr M. Schorr

$\mathrm{Nr}$ 3. Palestyna starożytna. Opracował dr M. Schorr

$\mathrm{Nr}$ 4. Iran i Indie. Opracował prof. dr A. Śmieszek i dr St. Schayer

Nr 5. Najdawniejsze dzieje Grecji. Opracował dr T. Wałek

$\mathrm{Nr}$ 6. Okres wojen perskich. Opracował dr J. Kowalski

$\mathrm{Nr}$ 7. Grecja od wojny peloponezkiej do podboju macedońskiego. Opracował J. Kowalski

$\mathrm{Nr}$ 8. Aleksander Wielki i epoka hellenistyczna. Opracował T. Wałek

$\mathrm{Nr}$ 9. Republika rzymska w dobie rozkwitu. Opracował dr L. Piotrowicz

$\mathrm{Nr}$ 10. Upadek republiki rzymskiej. Opracował dr L. Piotrowicz

$\mathrm{Nr}$ 11. Okres świetności cesarstwa rzymskiego. Opracował dr L. Piotrowicz

$\mathrm{Nr}$ 12. Rozkład i upadek cesarstwa rzymskiego. Opracował dr L. Piotrowicz

$\mathrm{Nr}$ 13. Europa we wczesnym średniowieczu. Opracował K. Dobrowolski

$\mathrm{Nr}$ 14. Polska pogańska i słowiańska. Opracował dr A. Brückner

$\mathrm{Nr}$ 15. Walka cesarstwa z papiestwem. Opracował dr Wł. Semkowicz

$\mathrm{Nr}$ 16. Budowa państwa polskiego (963-1138). Opracował dr R. Gródecki

$\mathrm{Nr}$ 17. Europa w okresie wypraw krzyżowych. Opracował dr Wł. Semkowicz

$\mathrm{Nr}$ 18. Podziały i zjednoczenie państwa polskiego (1138-1320). Opracował dr R. Grodecki

Nr 19. Rozkwit średniowiecznego porządku w Europie (w. XIII-XIV). Opracował dr J. Ptaśnik

$\mathrm{Nr}$ 20. Budowa wewnętrzna Polski piastowskiej. Opracował dr R. Grodecki

$\mathrm{Nr} 21$. Utwierdzenie państwa polskiego (1321-1334). Opracował dr J. Dąbrowski

$\mathrm{Nr}$ 22. Ruś i Litwa przed Unją. Opracował dr F. Koneczny

$\mathrm{Nr}$ 23. Europa w okresie schizmy i soborów. Opracował dr J. Dąbrowski

$\mathrm{Nr}$ 24. Korona i Litwa od chrztu Jagiełty do Warny (1385-1444). Opracował dr J. Dąbrowski

$\mathrm{Nr}$ 25. Arabowie i Turcy. Opracował dr T. Kowalski

$\mathrm{Nr}$ 26. Rozkład średniowiecznego porządku w Europie. Opracował dr J. Dąbrowski

$\mathrm{Nr}$ 27. Humanizm i rozkład średniowiecznego porządku w Europie. Opracował dr F. Papee

$\mathrm{Nr}$ 28. Odrodzenie i reformacja. Opracował dr L. Finkel i dr Wł. Pociecha

$\mathrm{Nr}$ 29. Polityka Europejska (1492-1555). Opracował dr L. Finkel i dr Wł. Pociecha

$\mathrm{Nr}$ 30. Panowanie Zygmunta Starego. Opracował dr Wł. Pociecha

$\mathrm{Nr}$ 31. Zygmunt August i rozkwit reformacji w Polsce. Opracował dr St. Kot

$\mathrm{Nr}$ 32. Europa $w$ dobie kontrreformacji. Opracował dr Wł. Pociecha

$\mathrm{Nr}$ 33. Polska za pierwszych królów elekcyjnych. Opracował dr St. Kot

$\mathrm{Nr}$ 34. Osłabienie władzy monarszej w Polsce (1587-1607). Opracował dr St. Kot

$\mathrm{Nr}$ 35. Okres wojny trzydziestoletniej. Opracował dr J. Feldman

$\mathrm{Nr}$ 36. Od rokoszu Zebrzydowskiego do wojen kozackich. Opracował dr K. Tyszkowski

$\mathrm{Nr}$ 37. Rewolucja angielska i jej następstwa. Opracował dr J. Feldman

$\mathrm{Nr}$ 38. Europa w okresie Ludwika XIV. Opracował dr J. Feldman

Nr 39. Panowanie Jana Kazimierza. Opracował dr Wł. Konopczyński

$\mathrm{Nr}$ 40. Polska w okresie wojen tureckich. Opracował dr Wł. Konopczyński

$\mathrm{Nr}$ 41. Europa w wieku oświecenia (1715-1789). Opracował dr J. Feldman

$\mathrm{Nr}$ 42. Czasy saskie w Polsce. Opracował dr Wł. Konopczyński

Nr 43. Panowanie Stanisława Augusta do roku 1788. Opracował dr Wł. Konopczyński

$\mathrm{Nr}$ 44. Wielka rewolucja francuska. Opracował dr A. Skałkowski

$\mathrm{Nr}$ 45. Polska od Sejmu Wielkiego do trzeciego rozbioru. Opracował dr A. Skałkowski 
Nr 46. Europa w okresie napoleońskim. Opracował dr A. Skałkowski

$\mathrm{Nr}$ 47. Legiony i Księstwo Warszawskie. Opracował dr A. Skałkowski

$\mathrm{Nr}$ 48. Europa w okresie Restauracji (1815-1847). Opracował dr J. Frejlich

Nr 49. Królestwo Kongresowe i Powstanie listopadowe. Opracował dr B. Pawłowski

Nr 50. Prusy i Austrja na ziemiach polskich przed r. 1846. Opracował dr J. Frejlich

Nr 51. Polska w dobie Wielkiej Emigracji (1815-1856). Opracował dr J. Frejlich

Nr 52. Ziemie litewsko-ruskie pod zaborem rosyjskim. Opracował H. Mościcki

Nr 53. Od wiosny ludów do wojny francusko-pruskiej. Opracował dr J. Frejlich

Nr 54. Powstanie styczniowe i reakcja. Opracował M. Dubiecki, prof. dr F. Bielak

Nr 55. Okres równowagi europejskiej (1871-1914). Opracował dr J. Frejlich

Nr 56. Ameryka i Daleki Wschód w polityce światowej. Opracował dr J. Frejlich

Nr 57. Polska w dobie przeobrażeń społecznych 1885 do 1904. Opracował dr J. Frejlich

Nr 58. Polska w latach ruchu niepodległościowego 1904-1918. Opracował dr J. Dąbrowski

Nr 59. Wojna Światowa i jej następstwa (1914-1922). Opracował dr J. Dąbrowski

Nr 60. Polska niepodległa (1918-1923). Opracował dr St. Kutrzeba 